\title{
IMPLEMENTASI KEBIJAKAN PELAYANAN PUBLIK BERBASIS APLIKASI PADA ERA COVID-19 DI KOTA CIMAHI PROVINSI JAWA BARAT
}

\author{
Oleh
}

\author{
Asri B. \\ Institut Pemerintahan Dalam Negeri \\ asribugis165@gmail.com
}

\begin{abstract}
$T$ The presence of the COVID-19 virus pandemic has been a challenge for Indonesian government governance. Good governance is a key requirement for dealing with the current COVID-19 pandemic. The COVID-19 pandemic changed new ways in various fields of community and state life, including for the Regional Government in managing the entire community service process to ensure all activities in various fields were running normally by adjusting to the conditions of the COVID-19 pandemic.

The application of new normal in an area requires intelligent City support to ensure that all regulations can be applied effectively and still pay attention to health protocols, so that life in various fields of life can run normally and is adaptive. Answering this problem the Cimahi City government, in public services in every agency in the Cimahi city environment, conducts public services carried out with application-based services, namely services that use smart city technology, which has been and has been implemented to all citizens of Cimahi City, so the authors in This research is interested in the extent of the implementation of Application-Based Public Service Policy in the City of Cimahi, this study uses descriptive qualitative methods and the results achieved can be concluded that application-based public services using smart city technology that is being developed in Cimahi City can run well, people get services as it should and is very useful. Application-based services, very effective, efficient and very fast and appropriate to be applied in this new normal condition, namely the condition of the adoption of new habits in the midst of a pandemic covid 19 that has not been completely finished.
\end{abstract}

Keywords: policy implementation, public service, application

\section{ABSTRAK}

$\mathrm{P}$ andemi virus corona (Covid-19) telah menjadi tantangan bagi tata kelola pemerintah Indonesia. Tata kelola pemerintah yang baik menjadi syarat utama untuk menangani pandemi COVID-19 saat ini, hal ini merubah cara-cara baru dalam berbagai bidang kehidupan bermasyarakat dan bernegara, termasuk bagi Pemerintah Daerah dalam mengelola seluruh proses pelayanan masyarakat untuk memastikan seluruh kegiatan di berbagai bidang berjalan secara normal dengan penyesuaian terhadap kondisi pandemi COVID-19. Penerapan new normal di suatu daerah memerlukan dukungan Kota yang cerdas untuk memastikan seluruh regulasi dapat diterapkan secara efektif dan tetap memperhatikan protokol-protokol kesehatan, sehingga kehidupan di berbagai bidang kehidupan dapat berjalan normal dan adaptif. 
Menjawab permasalahan ini pemerintah Kota Cimahi, dalam pelayanan publik di setiap instansi dalam lingkungan kota Cimahi, melakukan pelayanan publik dilakukan dengan layanan berbasis aplikasi, yaitu pelayanan yang menggunakan teknologi smart city, yang selama ini sedang dan telah diimplementasikan kepada seluruh warga Kota Cimahi, sehingga penulis dalam penelitian ini tertarik sejauh mana implementasi Kebijakan Pelayanan Publik Berbasis Aplikasi di Kota Cimahi, penelitian ini menggunakan metode kualitatif deskriptif dan hasil yang dicapai dapat disimpulkan bahwa pelayanan publik berbasis aplikasi dengan menggunakan teknologi smart city yang sedang dikembangkan di Kota Cimahi dapat berjalan dengan baik, masyarakat mendapatkan pelayanan sebagaimana mestinya dan sangat bermanfaat sekali. Pelayanan dengan berbasis aplikasi, sangat efektif, efisien dan sangat cepat dan tepat diterapkan pada kondisi new normal ini, yaitu kondisi adaptasi kebiasaan baru di tengah-tengah pandemic covid 19 yang belum selesai secara tuntas.

Kata kunci: implementasi kebijakan, pelayanan publik, aplikasi

\section{PENDAHULUAN}

Saat ini pandemi Corona Virus Disease $\mathcal{S}$ (Covid-19) masih terus terjadi di berbagai belahan dunia, secara umum wabah ini memiliki dampak yang cukup besar terhadap aktivitas dari berbagai aspek termasuk Indonesia. Mulai dari aspek ekonomi, sosial, hingga kehidupan sehari-hari, hampir tak ada yang bisa berkelit dari kemunculan Covid-19 ini, tidak terkecuali terhadap pelayanan publik sejak virus corona pertama kali muncul akhir Desember 2019 lalu. Sejak diumumkan kasus positif corona di Indonesia pada 2 Maret 2020 lalu, pemerintah meningkatkan langkahlangkah dalam menangani pandemi global tersebut. Sebelum itu, pemerintah juga telah meningkatkan kesesuain banyak rumah sakit dan peralatan yang sesuai dengan standar internasional, termasuk pada anggaran yang secara khusus dialokasikan bagi segala upaya pencegahan dan penanganan.

Berbagai kebijakan telah dikeluarkan oleh pemerintah pusat dan daerah. Diawali dengan membatasi hubungan sosial (social distancing), menghimbau untuk bekerja di rumah (work from home) bagi sebagian besar Aparatur Sipil Negara (ASN), meniadakan kegiatan ibadah, dan meminta masyarakat untuk tetap di rumah serta mengurangi aktivitas ekonomi di luar rumah. Kebijakan tersebut bermaksud baik, namun dampak dari kebijakan tersebut memiliki risiko tinggi, hingga akhir Maret 2020 kebijakan pemerintah bukan hanya social distancing tetapi dilanjutkan dengan Physical Distancing, dan juga pemerintah telah menetapkan Pembatasan Sosial Berskala Besar (PSBB).

Hal tersebut mengakibatkan sejumlah instansi penyelenggara layanan publik yang membatasi layanan, menginisiasi layanan online. Bahkan sampai meniadakan pelayanan sementara, menjadi satu fenomena yang harus dilakukan. Pembatasan pelayanan publik ini mulai dilakukan oleh pemerintah sejak pertengahan bulan Maret 2020 ini, dimulai dengan meliburkan anak sekolah dengan meminta untuk belajar di rumah dan kemudian menghimbau kepada pegawai untuk melakukan Work From Home (WFH).

Pemberlakuan work from home memang tidak diberlakukan kepada seluruh penyelenggara pelayanan publik, dikarenakan ada beberapa bidang yang tidak dapat melakukan work from home (WFH), seperti Dinas Kependudukan dan Pencatatan Sipil terkait dengan perekaman KTP-el, mengenai pembayaran pajak kendaraan bermotor maupun perpanjangan STNK di Samsat, dan bidang-bidang lain yang memerlukan kedatangan masyarakat secara langsung. Walaupun tidak memberlakukan work from home, tetapi tetap memberlakukan 
pembatasan pelayanan publik dengan cara mengurangi jumlah antrean yang masuk ke dalam ruangan dan di dalam ruangan, serta pelayanan harus mengikuti anjuran jarak aman, yaitu minimal 1 meter.

Dengan berlakunya work from home (WFH) bagi pegawai yang bergerak dalam pelayanan publik, menyebabkan pelayanan publik menjadi terhambat, karena pada akhirnya beberapa bidang pelayanan tidak dapat melayani masyarakat secara langsung. Akan tetapi, penyelenggara pelayanan publik kemudian membuat inovasi-inovasi dalam memberikan pelayanan agar pelayanan tidak terhambat seperti memberikan pelayanan melalui sistem online (menggunakan aplikasi).

Sistem online ini yang kemudian sedang digalakkan oleh beberapa penyelenggara pelayanan kepada masyarakat agar pelayanan publik tetap berjalan, di antaranya beberapa penyelenggara yang melakukan pelayanan menggunakan sistem online, yaitu PLN, pemberian pelayanan mulai dari penyambungan baru, perubahan daya sampai ke pengaduan serta dalam pembayaran melalui ATM atau internet banking. Kemudian DJP (Direktorat Jenderal Pajak) juga menghentikan pelaporan secara langsung dan mengarahkan secara online serta memperpanjang masa pelaporan pajak yang seharusnya berakhir pada 31 Maret 2020 menjadi tanggal 30 April 2020. Serta masih banyak lagi penyelenggara pelayanan publik yang menggunakan sistem online selama masa ini.

Berdasarkan Undang-Undang Nomor 25 Tahun 2009 tentang Pelayanan Publik sendiri, sebagai dasar dalam penyelenggara pelayanan publik dalam memberikan pelayanan tidakdiaturmengenai pembatasan pelayanan publik, sebagaimana yang diterapkan oleh penyelenggara pelayanan publik saat ini. Tetapi berdasarkan undangundang ini diatur bahwa penyelenggara pelayanan publik mempunyai kewajiban untuk memenuhi komponen standar pelayanan minimal seperti persyaratan, dasar hukum, sistem mekanisme prosedur, jangka waktu penyelesaian, biaya, produk layanan, dan lain-lain sesuai dengan Pasal 21 Undang-Undang No. 25 Tahun 2009, Sehingga walaupun ada kebijakan pembatasan pelayanan publik tersebut, penyelenggara pelayanan publik tetap harus mematuhi standar pelayanan minimal dengan tetap memperhatikan hak dan kewajiban masingmasing pihak baik penyelenggara maupun masyarakat, sebagaimana diatur dalam $B A B$ IV dari Pasal 14 sampai dengan Pasal 19, dalam Undang-Undang No. 25 Tahun 2009, tentang Pelayanan Publik.

Walaupun terjadi pembatasan dalam pemberian pelayanan publik, tetapi penyelenggara masih memberikan pelayanan publik yang efektif dan prima kepada masyarakat. Himbauan pemerintah untuk tetap berada di rumah dan pembatasan pemberian pelayanan publik ini memang membuat masyarakat menjadi kurang nyaman dalam menerima pelayanan publik, tetapi ini merupakan kebijakan yang saat ini diambil pemerintah adalah upaya untuk membatasi atau menghentikan penyebaran Corona Virus Disease (Covid-19) Dengan adanya pembatasan ini apakah kemudian hak-hak dari masyarakat dalam mendapatkan pelayanan publik menjadi berkurang? Itu merupakan pertanyaan mendasar dari sebagian besar masyarakat.

Adanya pembatasan pelayanan menjadi sedikit berkurang benefit yang diperoleh masyarakat dalam mendapatkan pelayanan publik. Akan tetapi, masyarakat tetap mempunyai hak untuk mendapatkan pelayanan publik yang baik, dan masyarakat mempunyai peran dalam pengawasan terhadap pembatasan pelayanan publik yang dilakukan oleh penyelenggara pelayanan publik. Peran masyarakat sesuai dengan Undang-undang adalah, untuk mengawasi jalannya pelayanan publik yang diselenggarakan oleh penyelenggara 
pelayanan publik. Seperti yang diatur dalam Undang-Undang No. 25 Tahun 2009, Pasal 39 menjelaskan bahwa, masyarakat seharusnya disertakan mulai dari penyusunan standar pelayanan sampai dengan evaluasi jalannya pelaksanaan pelayanan publik.

Dalam keadaan darurat dan mendesak saat ini akibat Corona Virus Disease (Covid-19) begitu cepat penyebarannya, masyarakat mungkin tidak dilibatkan dalam penyusunan standar pelayanan terkait pembatasan pelayanan publik. Akan tetapi, masyarakat masih mempunyai peran yang lain sebagaimana diatur dalam Pasal 35 ayat (3) Undang-Undang No. 25 Tahun 2009 bahwa masyarakat adalah sebagai pengawas eksternal dalam penyelenggaraan pelayanan publik.

Pengawasan penyelenggaraan pelayanan publik itu dapat dilakukan oleh pengawas internal dan eksternal, masyarakat yang merupakan pengawas eksternal dapat melakukan tugas pengawasannya dengan melalui laporan atau pengaduan, akan tetapi masyarakattidakbisamenilaiatau melakukan pengawasan secara penuh terkait standar layanan, dikarenakan kondisi sekarang masih tidak normal. Pengawasan yang dilakukan oleh masyarakat ini dilakukan dengan memastikan apakah pembatasan pelayanan publik yang dilakukan oleh penyelenggara ini masih memenuhi komponen-komponen dalam standar pelayanan, sesuai dengan yang diatur dalam Undang-Undang No. 25 Tahun 2009 pada Pasal 21, serta masyarakat masih mendapatkan haknya sebagaimana diatur juga dalam Pasal 18. (Sumber: Undang-Undang No. 25 Tahun 2009, tentang Pelayanan Publik).

Berdasarkan uraian di atas pemerintah Kota Cimahi mengalihkan pelayanan publik berbasis aplikasi dengan sistem online (daring) Pengurangan pelayanan tatap muka diharapkan dapat mencegah penyebaran Corona Virus Disease (Covid-19) di kawasan perkantoran tersebut. Peralihan pelayanan di antaranya diterapkan Dinas Kependudukan dan Catatan Sipil (Disdukcapil) Kota Cimahi mulai Kamis tanggal 19 Maret 2020. Untuk melayani masyarakat akan kebutuhan administrasi kependudukan (adminduk) dan catatan sipil Disdukcapil Kota Cimahi menyediakan 10 nomor layanan WhatsApp (WA) sesuai kebutuhan masyarakat. "Pemerintah Kota Cimahi menyampaikan permohonan maaf untuk ketidaknyamanan ini. Kontak langsung dan layanan tatap muka untuk sementara waktu ditutup, pelayanan dukcapil dialihkan secara online," ujar Kepala Dinas Komunikasi Informasi Arsip dan Perpustakaan (Diskominfoarpus) Kota Cimahi. Pengumuman telah dipasang Disdukcapil Kota Cimahi di ruang pelayanan, termasuk menyebarkan informasi ke wilayah kecamatan-kelurahan untuk disebarkan ke masyarakat.

Perkiraan masa penutupan loket pelayanan Disdukcapil Kota Cimahi berlangsung 14 hari. "Melihat perkembangan lebih lanjut. Selain Disdukcapil Kota Cimahi, sejumlah dinas lain menyusul akan membatasi pelayanan tatap muka. "Dinas Penanaman Modal dan Perizinan Terpadu Satu Pintu (DPMPTSP) juga mengoptimalkan layanan berbasis aplikasi online. Pelayanan umum sampai pukul 12.00 WIB, sisanya mengurus perizinan secara online. Bagi masyarakat yang datang untuk konsultasi tetap dilayani, namun seperlunya," katanya. Beberapa layanan pajak di Badan Pengelolaan Pendapatan Daerah (Bappenda) Kota Cimahi juga diproses untuk bisa dilakukan online. Dalam memerangi virus corona, kita perlu menerapkan upaya pencegahan agar covid-19 tidak muncul di Kota Cimahi.

Untuk lebih memadukan pelayanan berbasis aplikasi online ini, Pemda Kota Cimahi sedang dan telah mengembangkan bentuk pelayanan yang dilakukan melalui aplikasi berbasis smart city. Kota Cimahi telah ditunjuk oleh Pemerintah melalui Kementerian Kominfo menjadi Kota yang cerdas yang dapat membantu 
masyarakat dalam mengelola sumber daya yang ada secara efektif dan efisien untuk meningkatkan kualitas hidup. Smart City memiliki sasaran bagaimana mengatasi berbagai persoalan di perkotaan agar tercipta kehidupan lebih berkualitas. Tak mau tertinggal, Cimahi bergegas melakukan transformasi digital dan mewujudkan smarty city di kotanya. Cimahi telah menerapkan beberapa aplikasi teknologi informasi (TI) yang terintegrasi dan user friendly (mudah digunakan) untuk memberikan kemudahan pelayanan kepada masyarakat sekaligus mewujudkan mimpi smart city.

Salah satunya adalah melalui penerapan e-government sebagai upaya mewujudkan smart city dengan membuka ruang bagi masyarakat agar bisa semakin berperan aktif dalam pembangunan di kota Cimahi. Transformasi digital memberikan manfaat kepada kota Cimahi, yaitu perubahan perilaku baik dari masyarakat maupun ASN Kota Cimahi dalam proses implementasi pelayanan publik. Kini pelayanan Kota Cimahi menjadi lebih berkualitas dan cepat sehingga diharapkan dapat memenuhi harapan masyarakat. Untuk pengembangan dan pengelolaan serta sebagai leading sector TI di lingkungan Pemerintah Kota Cimahi dilaksanakan oleh Dinas Komunikasi Informasi Arsip dan Perpustakaan (Diskominfoarpus) Dalam hal ini setiap yang berkaitan dengan Pemanfaatan teknologi informasi dan komunikasi (TIK) yang akan maupun sudah diterapkan oleh semua unit kerja yang berada di Kota Cimahi terlebih dikoordinasikan melalui Diskominfoarpus.

Tentunya, transformasi digital dan smart city dapat terwujud dengan komitmen TOP Management di Kota Cimahi, yaitu Wali kota selaku Kepala Daerah yang senantiasa mendukung implementasi teknologi informasi dan komunikasi (TIK) di Kota Cimahi. TOP Management Kota Cimahi berkontribusi besar dalam membuat kebijakan, anggaran dan proses kerja untuk mewujudkan smart city di Kota Cimahi. "Pemkot Cimahi pun telah mengalokasikan anggaran sebesar 3 persen dari APBD Kota Cimahi yang tersebar di semua perangkat Daerah di Kota Cimahi untuk pengembangan TI dan smart city di kota Cimahi. Dengan anggaran itu, Pemkot Cimahi membangun monitoring Room dan data center di lingkungan Pemkot Cimahi serta membuat aplikasi e-Government dan Cimahi Smart City," Cimahi terus mengembangkan Aplikasi TI untuk mempercepat proses birokrasi seperti membuat aplikasi, di antaranya adalah Perizinan Online, E-Office, Sistem Administrasi Kelurahan (Simkel) dan Pengaduan Masyarakat. Kerja sama dengan pemerintah daerah lain juga sangat terbuka baik itu untuk pengembangan dan mewujudkan smart city. Peningkatan kualitas SDM di bidang TI juga terus dilakukan melalui berbagai pendidikan maupun pelatihan yang diselenggarakan oleh internal pemkot cimahi maupun pihak lain. Sedangkan untuk pengoperasian, pemerintah Kota Cimahi melaksanakan pengelolaan secara mandiri namun demikian untuk spesifikasi tertentu melibatkan jasa penyedia/vendor profesional pada bidangnya. Harapannya adalah agar proses layanan publik dapat dilakukan dengan cepat, murah dan baik. (Sumber: Diskominfoarpus Kota Cimahi)

Pemkot Cimahi telah melakukan beberapa tahap untuk melindungi data warehouse seperti melakukan backup data maupun aplikasi ke server cloud secara berkala, menerapkan sistem keamanan baik dari sisi jaringan maupun aplikasi berupa penerapan firewall dan service keamanan lainnya dalam satu wadah teknologi berupa Unifield Treath Management (UTM), penerapan teknologi enkripsi dalam pengiriman data melalui media internet, penerapan protokol aman (https) setiap alamat website/aplikasi dan penerapan sertifikat elektronik yang bekerja sama dengan Lembaga Sandi Negara (Lemsaneg). 


\section{Tantangan Smart City}

Citiasia Center for Smart Nation menyebut total nilai investasi pengembangan kota cerdas di seluruh Indonesia bisa menyentuh angka US $\$ 400$ miliar atau sekitar Rp5,4 triliun. Angka yang menggiurkan bagi mereka yang ingin berinvestasi di pengembangan teknologi smartcity. Apalagi, pemerintah menargetkan akan ada 100 kota cerdas hingga 2019 nanti. Bagi pelaku industri teknologi, ini tentu jadi peluang besar. Pelakunya pun terbilang masih minim di Indonesia.

Ada beberapa tahapan untuk membangun kota cerdas. Pertama adalah pembangunan infrastruktur dasar, yaitu penyediaan Internet. Salah satunya lewat pembangunan jaringan kabel fiber optik. Rampung dengan infrastruktur dasar, pembangunan pusat pengolahan data jadi fokus berikutnya. Setelah jejaring dan pengolahan data selesai, pemerintah bisa melanjutkan pengembangan dengan memasukkan dan mengolah data kota yang didapat dari sensor, aplikasi, atau lainnya.

\section{Manfaat Smart City}

Salah satu keuntungan konsep smart city adalah menciptakan perencanaan dan pengembangan kota layak huni yang lebih baik di masa depan. Implementasi smart city itu juga membuat sistem transportasi lebih efisien dan terintegrasi sehingga meningkatkan mobilitas masyarakatnya. Teknologi smart city juga mampu membuat rumah dan bangunan yang hemat energi dengan memakai sumber energi terbarukan. Selain itu, teknologi smart city dapat meningkatkan pelayanan kesehatan untuk masyarakat.

Untuk memaksimalkan penerapannya, smart city memiliki 6 konsep atau dimensi, antara lain sebagai berikut.

\section{Smart Governance}

Berbentuk pelayanan publik berbasis teknologi untuk memudahkan interaksi pemerintah dengan pemerintah dan pemerintah dengan warga. Pelayanan yang memungkinkan pengambilan keputusan berbasis real time data. Contohnya aplikasi Qlue yang diluncurkan Pemprov DKI untuk warga Jakarta.

\section{Smart Economy}

Layanan e-commerce dan e-business yang mendorong tingkat perekonomian masyarakat.

\section{Smart Mobility}

Penerapan sistem cerdas untuk mendukung dan memudahkan layanan transportasi publik, logistik, dan kenyamanan bagi pengendara atau pengguna jalan.

4. Smart Environment

Pemanfaatan sumber daya energi terbarukan, pengendalian polusi, penerapan konsep green building, sistem monitor, dan sebagainya.

5. Smart People

Masyarakat yang menjadi lebih cerdas karena mendapatkan kesempatan pendidikan dan pengembangan skill lebih besar dengan menerapkan teknologi dan sistem.

\section{Smart Living}

Pola hidup atau lifestyle yang cerdas, aman, dan sehat untuk kehidupan dan lingkungan yang lebih berkualitas, serta layak huni. (Sumber: Ahmad Sadli, Staf Bidang Informasi Komunikasi Publik pada Diskominfoarpus Kota Cimahi).

\section{Indentifikasi Masalah}

Berdasarkan pendahuluan yang telah diuraikan di atas, maka berbagai permasalahan diidentifikasi terkait implementasi kebijakan pelayanan publik berbasis aplikasi di Kota Cimahi antara lain sebagai berikut. 
1. Belum semua masyarakat mengetahui sistem aplikasi online

2. Sumber Daya Aparatur Pemerintah Kota Cimahi

3. Ketersediaan dukungan sarana dan prasarana yang wajib dipenuhi di Kota Cimahi

4. Belum semua masyarakat dapat menggunakan IT secara benar, sehingga mengalami hambatan dalam membutuhkan pelayanan publik berbasis aplikasi online

\section{Batasan Masalah}

Setelah diidentifikasi masalah di atas diperoleh gambaran permasalahan yang begitu luas, namun menyadari adanya keterbatasan waktu dan kemampuan, maka penulis memandang perlu memberi batasan masalah secara jelas dan terfokus. Selanjutnya masalah yang menjadi objek penelitian dibatasi hanya pada Implementasi kebijakan pelayanan publik berbasis aplikasi pada era covid-19 di Kota Cimahi

\section{Rumusan Masalah}

adapun masalah yang telah dikemukakan di atas, maka perlu dirumuskan suatu masalah yakni sebagai berikut. "Sejauh mana Implementasi Kebijakan Pelayanan Publik berbasis aplikasi pada era covid-19 di Kota Cimahi".

\section{KAJIAN PUSTAKA}

\section{Implementasi Kebijakan}

Implementasi kebijakan pada prinsipnya berusaha memahami apa yang senyatanya terjadi sesudah program dirumuskan yakni peristiwa-peristiwa dan kegiatankegiatan yang terjadi setelah proses kebijakan itu, baik menyangkut usaha-usaha mengadministrasikan maupun usaha-usaha untuk memberikan dampak tertentu pada masyarakat ataupun peristiwa-peristiwa. Pengertian Implementasi Kebijakan
Menurut Van Metter dan Van Horn dalam Agustino (2008: 195) menjelaskan bahwa: Implementasi kebijakan adalah "tindakantindakan yang dilakukan baik oleh individuindividu/pejabat-pejabat atau kelompokkelompok pemerintah atau swasta yang diarahkan pada tercapainya tujuan-tujuan yang telah digariskan dalam keputusan kebijakan".

Kemudian Solichin (1991:50) mendefinisikan bahwa implementasi kebijakan "sebagai suatu proses melaksanakan keputusan kebijakan". Sedangkan menurutPressman dan Wildavsky (dalam Jones, 1984:165) memandangnya "sebagai suatu proses interaksi antara tujuan yang ditetapkan dengan tindakantindakan yang dimaksudkan mewujudkan tujuan tersebut". Dapat kita pahami bahwa implementasi kebijakan adalah bagaimana memahami apa yang seharusnya terjadi sesudah suatu program dinyatakan berlaku atau dirumuskan. Pemahaman tersebut mencakup kegiatan untuk mengadministrasikannya dan menimbulkan dampak nyata pada masyarakat atas kejadian itu.

Esensi implementasi kebijakan dirumuskan oleh Mazmanian dan Sabatier dalam Agustino (2008: 196), yaitu sebagai berikut.

Implementasi kebijakan adalah pelaksanaan keputusan kebijakan dasar, biasanya dalam bentuk undang-undang, namun dapat pula berbentuk perintahperintah atau keputusan-keputusan eksekutif yang penting atau keputusan badan peradilan. Lazimnya, keputusan tersebut mengidentifikasikan masalahmasalah yang ingin diatasi, menyebutkan secara tegas tujuan dan sasaran yang ingin dicapai, dan berbagai cara untuk menstrukturkan atau mengatur proses implementasinya.

Berdasarkan uraian di atas, dapat dipahami bahwa implementasi kebijakan 
dapat dimaknai sebagai pelaksanaan kegiatan/aktivitas mengacu pada aturanaturan yang telah disiapkan sehingga dari kegiatan/aktivitas yang telah dilaksanakan tersebut dapat memberikan dampak/akibat bagi masyarakat dan dapat memberikan kontribusi dalam menanggulangi masalah yang menjadi sasaran program.

Implementasi kebijakan juga dapat dikaji dari sudut pandang siapa yang melihat proses implementasi kebijakan itu. Dalam setiap kebijakan pemerintah pasti akan melibatkan sejumlah pembuat kebijakan yang berusaha keras memengaruhi perilaku birokrasi/pejabat lapangan atau street level bureaucrats dalam rangka memberikan pelayanan atau jasa kepada kelompok sasaran.

\section{Pelayanan Publik}

Pelayanan pada dasarnya menyangkut aspek kehidupan yang sangat luas, dalam kehidupan bernegara pemerintah memiliki fungsi untuk memberikan pelayanan terbaik kepada masyarakat, mulai pelayanan dalam bentuk pengaturan atau pelayanan lain dalam rangka memenuhi kebutuhan. Menurut Moenir (2006:40) "Pelayanan itu menyangkut pemenuhan suatu hak, maka ia menjadi hak ikutan yang juga melekat pada setiap orang". Definisi lain pelayanan menurut Lukman (1999:6) adalah "Suatu kegiatan yang terjadi dalam interaksi langsung antara seseorang dengan orang lain atau mesin secara fisik, dan menyediakan kepuasan pelanggan".

Dari kedua pendapat di atas dipahami bahwa pelayanan adalah suatu proses atau kegiatan dalam rangka memenuhi kebutuhan manusia sesuai dengan haknya. Dari sisi pemerintahan menurut Pamudji (1994:28) bahwa "Pelayanan publik sebagai kegiatan yang bertujuan untuk memenuhi kebutuhan masyarakat akan barang-barang dan jasa-jasa". Sedangkan Djaenuri (1999:37) mendefinisikan pelayanan masyarakat adalah "Suatu kegiatan yang merupakan perwujudan dari tugas umum pemerintahan mengenai bidang tugas pokok suatu instansi untuk dapat melayani kebutuhan masyarakat secara maksimal".

Kaitan hal tersebut Triguno (1997:78) berpendapat bahwa "Pelayanan/ penyampaian terbaik, yaitu melayani setiap saat, secara cepat dan memuaskan, berlaku sopan, ramah dan menolong, serta profesional dan mampu". Hak mendapatkan pelayanan berlaku pada siapa pun, Hakhak dasar warga negara menurut Munir (2006:28) adalah "Seperangkat hak yang melekat pada setiap orang sejak orang itu dilahirkan, karena hak dasar itu melekat pada setiap orang, maka dengan sendirinya setiap orang mendambakan terpenuhinya hak itu, baik untuk diri pribadi, maupun untuk keperluan bersama melalui kerja sama”.

Berbagai definisi pelayanan di atas dapat diartikan bahwa segala bentuk kegiatan layanan dalam bentuk barang atau jasa dalam rangka upaya pemenuhan kebutuhan masyarakat. Pelayanan publik menurut Keputusan Menteri PAN Nomor 25 Tahun 2004 adalah segala kegiatan pelayanan yang dilaksanakan oleh penyelenggara pelayanan publik sebagai upaya pemenuhan kebutuhan penerima layanan, maupun dalam rangka pelaksanaan ketentuan peraturan perundang- undangan. Sedangkan Kepmen PAN Nomor 58 Tahun 2002 mengelompokkan tiga pelayanan dari instansi serta BUMN/ BUMD. Pengelompokan jenis pelayanan tersebut didasarkan pada ciri-ciri dan sifat kegiatan serta produk pelayanan yang dihasilkan, yaitu (1) pelayanan administratif, (2) pelayanan barang, (3) pelayanan jasa.

Jenis pelayanan administratif adalah jenis pelayanan yang diberikan oleh unit pelayanan berupa pencatatan, penelitian, pengambilan keputusan, dokumentasi dan kegiatan tata usaha lainnya yang secara keseluruhan menghasilkan produk lahir 
berupa dokumen, misalnya sertifikat, izinizin, rekomendasi, keterangan dan lain- lain. Misalnya jenis pelayanan sertifikat tanah, pelayaran, IMB, pelayanan administrasi kependudukan (KTP, NTCR, akte kelahiran, dan akte kematian).

\section{Aplikasi}

Aplikasi merupakan transformasi dari pekerjaan berupa hal yang sulit dipahami menjadi lebih sederhana, mudah dan dapat dimengerti oleh pengguna. Aplikasi terdiri dari perangkat lunak komputer yang memanfaatkan kemampuan komputer langsung untuk melakukan suatu tugas yang diinginkan pengguna. Dengan adanya aplikasi pekerjaan akan akan lebih cepat dan tepat. Definisi aplikasi menurut Jogiyanto dalam Ramzi (2013) adalah:

Merupakan penerapan, menyimpan sesuatu hal, data, permasalahan, pekerjaan ke depan suatu sarana atau media yang dapat digunakan untuk menerapkan atau mengimplementasikan hal atau permasalahan yang ada sehingga berubah menjadi suatu bentuk yang baru tanpa menghilangkan nilai-nilai dasar dari hal data, permasalahan, dan pekerjaan itu sendiri.

Sedangkan menurut Yuhefizar (2012) bahwa "aplikasi merupakan program yang dikembangkan untuk memenuhi kebutuhan pengguna dalam menjalankan pekerjaan tertentu". Hal yang tidak jauh berbeda di utarakan oleh Shelly, Cashman, Vermaat (2007) bahwa aplikasi adalah seperangkat instruksi khusus dalam komputer yang di rancang agar kita menyelesaikan tugas-tugas tertentu.

Terdiri beberapa pendapat di atas dapat diartikan bahwa aplikasi adalah berupa alat komputer yang digunakan oleh seorang pelayan untuk mempermudah berbagai ragam dalam menyelesaikan berbagai urusan dalam pelayanannya kepada masyarakat dengan muda dan cepat.
Aplikasi itu terdiri dari beberapa jenis, di antaranya aplikasi desktop yang beroperasi secara offline dan aplikasi web yang beroperasi secara online. menurut Ramzi (2013) bahwa aplikasi web adalah merupakan sebuah aplikasi yang menggunakan teknologi browser untuk menjalankan aplikasi dan diakses melalui jaringan komputer

Dapat kita ketahui bahwa aplikasi web merupakan aplikasi yang diakses menggunakan web browser melalui program jaringan internet. Program ini terdiri dari perangkat lunak yang menggunakan komputer dengan tujuan dapat mempermudah dalam melaksanakan pekerjaan atau tugas-tugas pelayanan yang diberikan aparatur atau pihak swasta dengan menggunakan seperangkat alat yang dapat digunakan secara online oleh pihak pelayan kepada pihak yang dilayani.

\section{Pengertian Smart City}

Smart city saat ini banyak diterapkan di berbagai kota di Indonesia, selain dikenal sebagai kota cerdas juga sebagai langkah yang trend dalam memajukan kota dengan berbasis teknologi informasi dan komunikasi (TIK) Secara sederhana sebagai kota pintar/ cerdas yang dapat memberikan kualitas hidup yang lebih baik dan kenyamanan bagi masyarakatnya. Smart city merupakan suatu konsep perencanaan, penataan dan pengelolaan kota yang saling terintegrasi dalam semua aspek kehidupan, guna mendukung masyarakat yang cerdas dan membantu penggunaan teknologi informasi dan komunikasi.

Kementerian Dalam Negeri dalam sebuah pemaparan Gerakan Menuju 100 Smart City pada Rabu, (15/5/2019) menjelaskan bahwa smart city atau yang biasa disebut dengan istilah "kota cerdas" bukan hanya fokus terhadap penerapan teknologi informasi melainkan juga fokus untuk peningkatan kualitas birokrasi 
dan pelayanan publik. Hal ini sangat beralasan karena UU No. 23 Tahun 2014 tentang pemerintah daerah menyebutkan penyelenggaraan pemerintah daerah diarahkan mewujudkan kesejahteraan masyarakat melalui peningkatan pelayanan publik, peran serta masyarakat dan daya saing daerah.

Aspek utama pembangunan smart city menurut Frost dan Sullivan (2014), yaitu smart governance, smart technology, smart infrastructure, smart healthcare, smart mobility, smart building, smart energy dan smart citizen. Tujuan dari smart city itu sendiri adalah untuk membentuk suatu kota yang nyaman, aman, serta memperkuat daya saing dalam perekonomian.

Sedangkan menurut Giffinger (2010) dalam Jung Hoon (2014) yang dikutip dari jurnal Hasibuan dan Sulaiman mengatakan bahwa smart city merupakan kota dengan investasi modal manusia dan sosial, dengan transportasi (tradisional) dan infrastruktur komunikasi modern serta pembangunan ekonomi yang berkelanjutan dan kualitas hidup yang tinggi, dengan manajemen SDA yang bijaksana melalui tata pemerintahan yang partisipatif.

Berdasarkan beberapa uraian di atas, penulis berasumsi bahwa smart city dapat membantu masyarakat yang berada di dalamnya dalam mengelola sumber daya yang ada dengan efisien dan memberikan informasi yang tepat kepada masyarakat/ lembaga dalam melakukan kegiatannya ataupun mengantisipasi kejadian yang tak terduga sebelumnya.

\section{Spesifikasi Smart City}

a. Smart Government (pemerintahan pintar)

Kunci utama keberhasilan penyelenggaraan pemerintahan adalah Good Governance., yaitu paradigma, sistem dan proses penyelenggaraan pemerintahan dan pembangunan yang mengindahkan prinsip-prinsip supremasi hukum.

b. Smart Economy (Ekonomi pintar)

Maksudnya ini adalah semakin tinggi inovasi-inovasi baru yang ditingkatkan maka akan menambah peluang usaha baru dan meningkatkan persaingan pasar usaha/modal.

c. Smart Mobility (mobilitas pintar)

Pengelolaan infrastruktur kota yang dikembangkan di masa depan merupakan sebuah sistem pengelolaan terpadu untuk menjamin keberpihakan pada kepentingan publik.

d. Smart People (orang/masyarakat pintar)

Pembangunan senantiasa membutuhkan modal, baik modal ekonomi, modal manusia maupun modal sosial.

e. Smart Living (Lingkungan pintar)

Lingkungan pintar itu berarti lingkungan yang bisa memberikan kenyamanan, keberlanjutan sumber daya, keindahan fisik maupun non fisik, visual maupun tidak, bagi masyarakat dan publik.

f. Smart Live (Hidup pintar)

Berbudaya, berarti bahwa manusia memiliki kualitas hidup yang terukur (budaya)

\section{Konsep Smart City}

a. Sebuah kota berkinerja baik dengan berpandangan ke dalam ekonomi, penduduk, pemerintahan, mobilitas, lingkungan hidup.

b. Sebuah kota yang mengontrol dan mengintegrasi semua infrastruktur termasuk jalan, jembatan, terowongan, rel, kereta bawah tanah, bandara, pelabuhan, komunikasi, air, listrik, dan pengelolaan gedung.

c. Smart city dapat menghubungkan infrastruktur fisik, infrastruktur IT, infrastruktur sosial, dan bisnis 
infrastruktur untuk meningkatkan kecerdasan kota.

d. Smart city membuat kota lebih efisien dan layak huni

e. Penggunaan smart computing untuk membuat smart city dan fasilitasnya meliputi pendidikan, kesehatan, keselamatan umum, transportasi yang lebih cerdas, saling berhubungan dan efisien.

\section{Kegunaan Smart City}

a. Bagaimana kita melestarikan lingkungan, meningkatkan daya saing ekonomi dan membangun masyarakat yang madani.

b. Memperbaiki permasalahan di masyarakat

c. Meningkatkan layanan publik

d. Menciptakan pemerintahan yang lebih baik

e. Mencerdaskan masyarakat

f. Mengelola potensi kota dan potensi SDM

\section{Faktor-Faktor yang Memengaruhi Terwujudnya Smart City}

Untuk mendukung sebuah wilayah negara sukses sebagai kota cerdas tentunya didukung oleh berbagai faktor, antara lain, yaitu:

a. Manajemen dan Organisasi, suatu organisasi harus memiliki manajemen yang terstruktur agar organisasi tersebut berjalan baik, seimbang dan lancar. Dalam hal ini faktor organisasi dan manajemen merupakan faktor yang menentukan kemajuan terciptanya smart city, karena manusia yang membuat tujuan dan manusia pula yang melakukan proses untuk mencapai tujuan.

b. Teknologi Sebuah smart city sangat bergantung pada smart computing. Smart computing mengacu pada generasi baru hardware, software dan jaringan teknologi yang menyediakan sistem IT yang real-time. Dengan analisis yang baik dan secara mendalam dapat membantu penduduk membuat keputusan yang lebih pintar yang diiringi dengan tindakan yang dapat mengoptimalkan proses bisnis. Teknologi informasi merupakan sebuah pendorong utama bagi inisiatif smart city. Proyek pembangunan smart city dengan mengacu pada teknologi informasi dapat mengubah sejumlah peluang yang potensial, mereka dapat meningkatkan manajemen dan fungsi kota. Namun, meskipun banyak manfaat dari teknologi tersebut dampaknya masih belum terlihat jelas, karena terdapat kesenjangan sosial bagi penduduk yang tinggal di perdesaan yang belum mendapatkan fasilitas tersebut. Maka dari itu pemerintah kota harus banyak mempertimbangkan faktor-faktor tertentu ketika mengimplementasikan teknologi informasi yang berkaitan dengan sumber daya, kapasitas, dan halhal yang berkaitan dengan kesenjangan sosial nantinya.

c. Pemerintahan beberapa kota di negara berkembang sudah memulai proyek pembangunan smart city yang inisiatif. Proyek ini disebut inisiatif smart city untuk melayani warga dan untuk meningkatkan kualitas hidup mereka. Dengan demikian, beberapa kota telah merasakan peningkatan kebutuhan pemerintahan untuk mengelola proyek. Dukungan dari pemerintah juga merupakan salah satu faktor yang penting untuk kemajuan smart city. Karena tanpa dukungan pemerintah impian untuk mewujudkan smart city akan sulit untuk diwujudkan.

d. Kebijakan Perpindahan dari sebuah kota biasa menjadi smart city memerlukan interaksi komponen teknologi dengan politik dan kelembagaan. Komponen 
politik mewakili berbagai elemen dan tekanan eksternal, seperti kebijakan politik yang mungkin memengaruhi ide dari pembuatan smart city. Konteks kebijakan sangat penting bagi pemahaman dari penggunaan sistem informasi. Pemerintah yang inovatif yang ikut serta dalam membangun smart city menekankan perubahan dalam suatu kebijakan.

e. Masyarakat merupakan bagian penting dari terciptanya smart city, dengan demikian kebiasaan yang dulu mulai ditinggalkan. Proyek smart city berdampak pada kualitas hidup warga dengan tujuan menjadikan sebuah kota menjadi lebih efisien. Masyarakat juga dituntut untuk ikut berpartisipasi dalam pengelolaan dan penyelenggaraan kota, serta menjadi pengguna kota yang aktif. Masyarakat juga adalah factoryang paling menentukan keberhasilan atau kegagalan terciptanya smart city.

f. Faktor ekonomi merupakan pendorong utama smart city. Sebuah kota dengan daya saing ekonomi yang tinggi dianggap memiliki salah satu sifat smart city. Faktor ekonomi termasuk salah satu daya saing inovasi, kewirausahaan, dan produktivitas dari kota tersebut.

g. Infrastruktur memegang peranan penting dalam membuat smart city. Karena smart city dibangun berdasarkan infrastruktur ICT seperti wi-fi dan hotspot. Pembangunan infrastruktur ICT merupakan hal yang mendasar dalam melakukan pembangunan smart city. Pembangunan infrastruktur tergantung pada beberapa faktor yang terkait untuk kinerja dan ketersediaannya.

h. Faktor lingkungan dianggap sebagai faktor yang memengaruhi kemajuan smart city karena nantinya lingkungan sebuah kota menggunakan teknologi dalam menjalani kelangsungan hidup masyarakatnya

\section{Tujuan Smart City}

Tujuan dari konsep smart city ini adalah untuk mengatasi berbagai karakteristik inovasi ekosistem oleh semua gagasan di antaranya menjadi kota hijau, saling berhubungan, terpadu untuk semua lapisan dan bentuk kota. Perencanaan smart city menggunakan model referensi untuk menentukan konsep tata letak kota yang cerdas dan berkarakter. Smart city ini pada intinya memiliki 6 dimensi, yaitu ekonomi yang cerdas, mobilitas cerdas, lingkungan pintar, orangnya cerdas, cerdas dalam hidup dan akhirnya pemerintahan yang cerdas pula. Konseptual Smart city dapat digunakan juga untuk evaluasi kemampuan inovatif perencanaan kota. Selain itu model ini juga dapat untuk sinkronisasi dan pengoptimalan kota investasi dalam ekonomi dan broad band. Tujuan utama dari pembangunan sebuah "Kota Pintar" (Smart City) adalah bagaimana kita melestarikan lingkungan, meningkatkan daya saing ekonomi dan membangun masyarakat yang madani.

Pemkot Cimahi, saat ini sedang mengembangkan konsep smart city secara terintegrasi, sehingga menjadikan Cimahi Kota cerdas, seperti apa yang didampakkan akan segera terwujud. dan pelayanan publik kelak akan terintegrasi secara terpadu dan mudah dikontrol oleh Wali kota Cimahi.

\section{METODELOGI PENELITIAN}

Metodologi penelitian merupakan sebuah cara untuk menentukan kadar keilmiahan suatu penelitian. Penelitian ini termasuk ke dalam penelitian kualitatif, dengan menggunakan analisis deskriptif. Menurut Bogman dan Taylor dalam Moleong (1997:3) metode penelitian kualitatif sebagai prosedur penelitian yang menghasilkan data deskriptif berupa kata tertulis atau lisan dari orang-orang dan perilaku yang dapat diamati. Berkaitan hal tersebut Poerwandari (1998:3) mengatakan bahwa penelitian kualitatif 
adalah "penelitian yang menghasilkan dan mengolah data yang sifatnya deskriptif, seperti transkripsi wawancara, catatan lapangan, dan lain-lain".

Kendati demikian, pendekatan kualitatif menekankan pada makna, penalaran, definisi suatu situasi tertentu, lebih banyak meneliti hal-hal yang berhubungan dengan kehidupan sehari-hari. Menginterpretasikan sesuatu fenomena, misalnya kondisi atau hubungan yang ada, pendapat yang berkembang dengan menggunakan prosedur ilmiah untuk menjawab masalah secara aktual yang salah satunya bersumber dari informan.

Informan adalah teknik sampling purposif (purposive sampling) Teknik ini mencakup orang-orang yang diseleksi atas dasar kriteria kriteria tertentu yang dibuat berdasarkan tujuan riset. Menurut Spradley dalam Moleong (2004: 165) bahwa informan memiliki beberapa kriteria yang harus dipertimbangkan, yaitu sebagai berikut.

1. Subjek yang telah lama dan intensif menyatu dengan suatu kegiatan atau lokasi aktivitas yang menjadi target atau perhatian penelitian, dan ini biasanya ditandai oleh kemampuan emberikan informasi di luar kepala tentang sesuatu yang ditanyakan.

2. Subjek masih terikat secara penuh serta aktif pada lingkungan dan kegiatan yang menjadi sasaran penelitian.

3. Subjek mempunyai cukup banyak waktu dan kesempatan untuk dimintai informasi.

4. Subjek yang dalam memberikan informasi tidak cenderung di olah atau dikemas terlebih dahulu dan mereka masih relatif masih jujur dalam memberikan informasi.

Penelitianini dilakukan pemilihan kriteria agar pengumpulan data dapat tercapai, kriteria yang dimaksud adalah menentukan informan untuk mendapat data dan informasi yang aktual. Sedangkan sumber data meliputi data primer dan data sekunder. Data primer, adalah data yang diperoleh langsung dari lapangan yang diperoleh melalui pengamatan langsung maupun hasil wawancara. Data sekunder adalah data yang diperoleh peneliti dari berbagai sumber, data dalam penelitian ini adalah berupa buku-buku dan dokumen lain yang berhubungan dengan penelitian.

Pengumpulan data dalam penelitian ini dilakukan melalui beberapa teknik antara lain sebagai berikut.

1) Dokumentasi, yaitu pengumpulan data dengan cara mempelajari, menelaah berbagai peraturan-peraturan, bukubuku, serta dokumentasi yang ada relevansinya dengan masalah yang diteliti.

2) Wawancara, yaitu pengumpulan data dengan cara mengajukan pertanyaan secara langsung kepada orang-orang yang dipilih berdasarkan pertimbangan tertentu. Nazir (2014:170) wawacara adalah "proses memperoleh keterangan untuk tujuan penelitian dengan cara tanya jawab, sambil bertatap muka antara si penanya atau pewawancara dengan yang ditanya atau responden dengan menggunakan alat yang dinamakan interview guide (panduan wawancara) Wawancara tidak selalu secara langsung melainkan bisa melalui telepon, untuk menghindari penyebaran covid-19, maka wawancara yang dilakukan penulis adalah melalui telepon. Menurut Sugiyono (2014:75) bahwa "wawancara baik yang dilakukan dengan face to face maupun yang menggunakan pesawat telepon, akan selalu terjadi kontak pribadi, oleh karena itu pewawancara perlu memahami situasi dan kondisi sehingga dapat memilih waktu yang tepat kapan dan di mana harus melakukan wawancara". 
3) Observasi, yaitu pengumpulan data dengan cara mengadakan pengamatan langsung di lapangan dan mencatat masalah-masalah penting yang ada hubungannya dengan penelitian.

\section{HASIL DAN PEMBAHASAN}

Pemerintah Kota Cimahi, di tengah pandemic covid 19 yang belum menentu kapan akan berakhir, melaksanakan pelayanan publik menggunakan aplikasi berbasis online, hal ini sejalan dengan kebijakan Wali kota Cimahi, yang menginginkan semua pelayanan untuk masyarakat tidak boleh terhenti walaupun adanya musibah covid 19 di Kota Cimahi.

Ada beberapa pelayanan publik yang tidak dapat dilakukan dengan aplikasi secara online, yaitu pelayanan pada Dinas Kependudukan dan Catatan Sipil, ini menyangkut perekaman e-KTP, di mana apabila ada warga yang membutuhkan pembuatan KTP, warga itu sendiri harus datang kepada Kantor Dinas layanan, karena harus ada perekaman setiap individu yang menginginkan pelayanan e-KTP. dan Pelayanan pembuatan SIM dan Perpanjangan STNK atau balik nama kendaraan bermotor, ini dilakukan secara manual, di mana mereka harus datang ke kantor Samsat Pelayanan Terpadu di Kota Cimahi, Kendati demikian, pelayanan dilakukan dengan pembatasanpembatasan dari jumlah warga masyarakat yang menginginkan pelayanan terpadu di Kantor Samsat Kota Cimahi, dan dengan menjaga jarak antrean satu dengan yang lainnya, menggunakan masker, serta jam operasionalnya dibatasi secara proporsional setiap harinya, pemerintah Kota Cimahi tetap menerapkan protokol kesehatan bagi warga masyarakat yang menginginkan pelayanan publik harus datang mengunjungi kantorkantor pelayanan publik.
Pemerintah Kota Cimahi sejalan dengan Visi dan Misi Kota Cimahi yang terus mengembangkan bentuk pelayanan publik berbasis aplikasi menuju smart city. Di mana Transformasi layanan publik dari selama ini dilakukan secara manual, kini bentuk layanan publik dilakukan dengan teknologi terintegrasi dengan penyesuaian kebutuhan daerah Kota Cimahi, dan ditargetkan selama dua tahun menyediakan kemudahan aksesibilitas layanan bagi masyarakat.

Gerakan Menuju 100 Smart City merupakan program bersama Kementerian Komunikasi dan Informatika, Kemendagri, Kemen PUPR, Bappenas, dan Kantor Staf Kepresidenan. Gerakan tersebut bertujuan agar seluruh pemerintah daerah dapat memaksimalkan pemanfaatan teknologi dalam meningkatkan pelayanan kepada masyarakat. Melalui gerakan ini, pemerintah kota dan kabupaten akan mendapatkan bimbingan dari tim ahli yang dibentuk Pemerintah Pusat. Tim tersebut akan membantu meletakkan aspek-aspek fundamental dalam pengembangan smart city dan mendampingi dalam pembuatan master plan smart city kab/kota. "Tidak bisa dihindari, saat ini perkembangan teknologi tanpa batas yang perlu kita respons sesuai tren pemanfaatan teknologi dalam berbagai bidang, termasuk pelayanan publik. Tujuannya agar berbagai pelayanan terhadap masyarakat bisa lebih cepat dan efisien. Dengan teknologi, kecepatan pelayanan lebih bisa tercapai,"

Esensi tagline Cimahi Baru, pihaknya mengklaim sudah ada 66 aplikasi dan berbagai inovasi dari SKPD, Forkopimda, dan komunitas masyarakat. "Dinas-dinas yang belum agar segera membuat konsep aplikasi pelayanan yang bisa diterapkan secara mudah oleh masyarakat," Contohnya, di Kecamatan Cimahi Utara yang sudah memiliki aplikasi pelayanan Sasarengan Lengkapi Persyaratan 
(Sapakat) dan Surat Pelayanan Terpadu (Super) online. "Pelayanan RSUD Cibabat juga sedang dibuat. Kita juga akan coba di RT/RW. Kecamatan Cimahi Tengah dan Cimahi Selatan juga tengah mengembangkan hal serupa," Secara infrastruktur di Kota Cimahi sudah mumpuni untuk penerapan konsep layanan berbasis teknologi. Keberadaan fiber optik di wilayah Cimahi sudah panjang ternyata, tinggal disambungsambungkan saja sehingga benar-benar dapat dimanfaatkan. Penerapan 'smart city', memang sudah seharusnya karena kebutuhan dalam layanan pemerintahan, bukan lagi wacana.

Pada era kepemimpinan Wali Kota Cimahi Itoc Tochija, muncul konsep pengembangan Kota Cyber Cimahi (Cimahi Cyber City/CCC) Pembangunan Baros Information Technology and Creative (BITC) sebagai ikon sekaligus pusat pengembangan bisnis industri kreatif khususnya di bidang telematika menjadi salah satu ikon CCC. Terkait relevansinya dengan Smart City, bisa terwujud optimal saat ini. "Mungkin pada dasarnya tujuannya sama. Hanya, sekarang lebih luas jaringan kerja sama dan kesempatan dalam penerapan teknologi sehingga bisa diwujudkan.

Untuk menjamin keberlanjutan program smart city, diperlukan regulasi dalam bentuk Perda atau Peraturan Wali Kota. "Konsistensi diperlukan dalam pembangunan Smart City. Tujuan akhirnya, dari program Smart City dapat berimbas pada peningkatan kualitas sumber daya manusia. Pelaksana Tugas (Plt) Kepala Dinas Komunikasi Informasi Arsip dan Perpustakaan (Diskominfoarpus), seluruh Satuan Kerja Perangkat Daerah (SKPD) di lingkungan Pemerintah Kota Cimahi harus siap menyesuaikan konsep 'Smart City'. "Dinas harus siap karena MoU sudah ditandatangani Wali Kota.
Dalam mengembangkan Smart City, ada beberapa unsur pelayanan yang akan dimasukkan. Di antaranya pelayanan bidang ekonomi, hunian, tata kelola pemerintahan, lingkungan dan lain-lain. "Tujuannya bagaimana pemerintah memudahkan warganya dalam aksesibilitas, terutama pelayanan," katanya. Untuk penerapan di Kota Cimahi, diawali dengan sosialisasi kepada SKPD. Kemudian akan ditindaklanjuti dengan bimbingan teknis dan pembuatan masterplan Cimahi Smart City. Serta membentuk lembaga yang mendukung penerapan Smart City seperti Dewan Smart City dan Tim Pelaksana Smart City Kota Cimahi. "Khusus pembuatan masterplan, harus selesai selama empat bulan pasca Bimbingan Teknis (Bimtek) Yang ada saat ini, aplikasi layanan publik masih parsial dan berdiri sendiri. Jadi, sistem semuanya harus terintegrasi untuk memudahkan pelayanan juga," katanya.

Kebijakan ini ditempuh oleh Pemerintah Kota Cimahi, agar pelayan publik yang dibutuhkan oleh Masyarakat pada era pandemic covid 19 tetap berjalan, dan masyarakat mendapatkan pelayanan publik sebagaimana mestinya. Pelayanan Publik menggunakan aplikasi berbasis online dirasakan sangat efektif dan efisien, di mana masyarakat tidak perlu datang ke kantor pelayanan publik, cukup hanya menggunakan HP berbasis android, atau bagi warga masyarakat yang memiliki computer system, cukup hanya menggunakan aplikasi kantor pelayanan publik, maka pelayanan yang dibutuhkan akan dapat dilayani secara cepat, dengan mematuhi semua kelengkapan yang diperlukan. Dari aspek biaya sangat hemat, di mana masyarakat tidak perlu mengeluarkan ongkos untuk datang ke kantor pelayanan publik. dan semua jenis pelayanan telah dibebaskan atau tidak dipungut biaya, hanya ada beberapa pelayanan yang harus 
mengeluarkan biaya, yaitu pembuatan SIM, pembuatan STNK, pajak kendaraan bermotor, pajak PBB. P2. Itu pun yang dikeluarkannya bukan untuk petugas yang melayani tetapi untuk membayar besaran pajak yang harus dibayar oleh warga masyarakat, sebagai wajib pajak selama ini.

Hasil wawancara dengan salah seorang warga masyarakat Kota Cimahi Pada 12 juli 2020 atas nama Ujang Suwandi, mengatakan bahwa Masyarakat pada umumnya sangat merasakan kecepatan aspek pelayanan publik, yang semakin baik dan cepat, sehingga masyarakat merasakan manfaatnya adanya pelayanan publik berbasis smart city di Kota Cimahi terutama pelayanan KTP. Hal yang tidak jauh berbeda yang dirasakan oleh masyarakat lain atas nama Lilis mengatakan bahwa saya merasakan terbantu dengan adanya pelayanan online ini. Sedangkan Undang Ronandi merasakan manfaat dengan adanya pelayanan publik yang menggunakan aplikasi online karena tidak ikut lagi atri di kantor pelayanan seperti dulu, terutama di tengah pandemic covid 19 ini.

\section{SIMPULAN}

Pelayanan publik di Kota Cimahi, di tengah pandemic covid 19, tetap berjalan, pihak pemerintah tetap melaksanakan protokol kesehatan, hanya beberapa pelayanan publik yang tidak menggunakan aplikasi online, yaitu pembayaran pajak kendaraan, perpanjangan STNK, Balik nama kendaraan bermotor, pembuatan SIM, di kantor Samsat Kota Cimahi, dan pembuatan e-KTP di Kantor Dinas Kependudukan dan Catatan Sipil. Pelayanan publik lainnya sudah menggunakan aplikasi secara online, di mana warga masyarakat yang membutuhkan pelayanan publik, tinggal hanya menghubungi secara online dengan menggunakan aplikasi dari web site di masing-masing dinas pelayanan yang ada di Kota Cimahi, semua bentuk pelayanan publik di kota Cimahi dilakukan secara gratis dalam arti tidak membutuhkan biaya dari warga masyarakat.

Jika smart city sudah dapat digunakan secara terintegrasi dengan aplikasi yang selama ini digunakan oleh Pemkot Cimahi, ke depan pelayanan publik dapat menggunakan pelayanan publik berbasis smart city. Karena kota Cimahi saat ini sedang dan telah mengembangkan konsep smart city, yaitu Kota Cimahi yang menjadi Kota Cerdas. Kota Cimahi dalam mendukung pelayanan publik berbasis aplikasi IT, seperti smart city, didukung oleh seluruh jajaran aparatur pemerintah daerah Kota Cimahi, dan jajaran DPRD Kota Cimahi dan warga masyarakat Kota Cimahi.

Salah satu dukungan dari DPRD Kota Cimahi adalah dukungan besarnya anggaran yang dialokasikan bagi pelayanan publik berbasis aplikasi smart city, dan pelayanan publik berbasis aplikasi smart city merupakan suatu contoh sebuah kota metropolitan yang dapat dinilai sudah maju dan dapat dikatakan Kota yang memiliki sebuah konsep pengembangan ke depan dengan konsep berbasis aplikasi smart city.

Warga masyarakat sangat menikmati semua pelayan berbasis onlineyang diberikan oleh pemerintah Kota Cimahi, Ujang Suwandi, Lilis dan bpk Undang Ronandi dan Ima pada saat peneliti berkunjung ke lokasi Kota Cimahi, mereka sangat merasakan kecepatan aspek pelayanan publik, yang semakin baik dan cepat, sehingga masyarakat merasakan manfaatnya adanya pelayanan publik berbasis smart city di Kota Cimahi

\section{SARAN}

Walaupun bentuk pelayanan publik sampai saat ini masih berjalan dengan baik, 
namun untuk lebih efektif dan efisiensi dalam bentuk pelayanannya perlu diatur agar lebih efektif dalam melayaninya, karena warga masyarakat yang membutuhkan pelayanan publik memiliki jadwal yang jelas dan menggunakan semacam SOP dalam pelayanan yang simpel dan praktis, karena tidak semua warga masyarakat Kota Cimahi paham akan aplikasi online, dan tidak semua warga Kota Cimahi mengoperasionalkan handphone (HP) berbasis android system. Perlu adanya semacam juknis-juknis yang dapat disosialisasikan kepada masyarakat oleh dinas-dinas yang bertanggung jawab atas pelayanan publik ini. dan seyogianya semua bentuk pelayanan yang harus diberikan kepada masyarakat dilakukan dengan gratis, tanpa dipungut biaya apa pun.

Pemerintah yang baik, menggratiskan semua bentuk pelayanan kepada masyarakat. Agar masyarakat merasakan manfaat atas pajak yang selama ini dibayar oleh mereka. Perlu ditingkatkan fungsi pengawasan dan pengendalian atas semua bentuk pelayanan publik yang dilakukan jajaran aparatur pemerintah Kota Cimahi.

\section{DAFTAR PUSTAKA}

Agustino, Leo, 2008, Dasar-dasar Kebijakan Publik, Alfabeta: Bandung

Frost \& Sullivan, 2014, Strategic Opportunity Analysis of the Global Smart City Market.

Moenir, H. A. S., 2006, Manajemen Pelayanan Umum di Indonesia, PT Bumi Aksara, Jakarta.

Moleong, Lexy J, (2004), Metodologi Penelitian Kualitatif, Bandung: PT. Remaja Rosdakarya

Nazir, Moh, 2014, Metode Penelitian, Bogor: Ghalia Indonesia

Pamudji, 1994, Profesionalisme Aparat Negara Dalam Meningkatkan Pelayanan Publik, dalam Widyapraja Nomor 19, IIP, Jakarta.

Poerwandari, E. K. 1998, Pendekatan Kualitatif Dalam penelitian Psikologi, Jakarta: Lembaga Pengembangan Sarana Pengukuran dan Pendidikan Psikologi (LPSP3) Fakultas Psikologi Universitas Indonesia.

Riyanto, Adi, 2017, Implementasi Konsep Smart City dalam Aspek Fisik Lingkungan Kota Cimahi: Bandung.

Solichin, Wahab, Abdul, 1991, Analisis Kebijakan dari Formulasi ke Implementasi Kebijakan Negara. Jakarta: Bumi Aksara.

Triguno, 1997, Budaya Kerja, Menciptakan Lingkungan yang kondusif untuk Meningkatkan Produktivitas Kerja, Golden Teravon Press, Jakarta

Yuhefizar, 2012, Cara Mudah Membangun Website Interaktif Menggunakan CMS Joomla Edisi Revisi, PT. Elex Media Komputindo: Jakarta

Peraturan Perundang-undangan

Undang-Undang Republik Indonesia Nomor 23 Tahun 2014 tentang Pemerintahan Daerah

Kepmen PAN Nomor 25 Tahun 2004, tentang Pelayanan Publik

Kepmen PAN Nomor 58 Tahun 2002, Pengelompokan Pelayanan dan Pelayanan BUMN dan BUMD

Peraturan Daerah Nomor 4 Tahun 2013 tentang RT RW Kota Cimahi 2012- 2032

Keputusan Wali Kota Cimahi yang terbaru Nomor: 490.05/Kep.3 Diskominfoarpus/2017 tentang Tim Penanganan Pengaduan Masyarakat

\section{Sumber Lain}

file://C:/Users/ASUS/Downloads/1097-26782-PB. Pdf (diuduh tgl 1-08-2020)

http://sir. Stikom. Edu/100/5/BAB\%20III. Pdf. Diakses tanggal 27-08-2017 
http://www. Academia. Edu/12154895/_ PERENCANAAN_KOTA_KONSEP_PENGE

ANGAN_KOTA_Green_City_Smart_City_Compact_ City_Mega_City_Kota_Satelit_Baru

http://www. Pikiran-rakyat.com/bandungraya/2018/05/23/cimahi-menujusmart-city-layanan-berbasis-aplikasiterus-dikembangkan-424845
Sumber: http://www. Pikiran-rakyat.com/ bandung-raya/2018/05/23/cimahimenuju-smart-city-layanan-berbasisaplikasi-terus-dikembangkan-424845 